\title{
De impact van genetisch onderzoek: een familiegeschiedenis
}

\author{
Deborah M. Ligtenberg
}

Published online: 14 February 2020

(c) The Author(s) 2020

"Dat zoveel familieleden me al voorgingen, is vreselijk. Er is zóveel kanker in onze familie," vertelt Wim (84). Wim heeft sinds 2008 prostaatkanker. Er zitten uitzaaiingen in zijn longen en botten. Toen zijn jongste broer in augustus hoorde dat hij prostaatkanker had, had Wim niet verwacht dat hij hem zou overleven. "Ik had het gevoel dat we bezig waren met een survivaltocht, waarbij we in een gammele kano zaten op een kolkende rivier. Ik vroeg me af wie er als eerste overboord werd geslingerd. Bij mij is de ziekte al ver, maar toch ging mijn broer eerst. Zeven weken na de diagnose overleed hij. Dat was een geweldige klap." "Vanwege prostaatkanker en een BRCA-mutatie in onze familie, werd het PSA-gehalte van mijn oom regelmatig gecontroleerd", vult Wims dochter Béatrice (46) aan (fig. 1). "De waarde was niet alarmerend. Het was een schok dat hij prostaatkanker in een vergevorderd stadium had." Het bleek een zeldzame kleincellige vorm te zijn.

De BRCA-mutatie in de familie kwam aan het licht nadat Béatrice eind 2013 borstkanker kreeg. Vanwege haar jonge leeftijd en het feit dat de tumor 'triple negatief' was, werd zij doorverwezen voor DNA-onderzoek. Bij deze vorm van borstkanker heeft de tumor geen receptoren voor oestrogeen en progesteron en ontbreekt ook het eiwit HER2. Deze triple-negatieve vorm komt vaak voor bij een BRCA1-mutatie. "Voordat ik geopereerd werd, wilde ik de uitslag van het erfelijkheidsonderzoek weten", vertelt ze. "Die was voor mij mede bepalend voor de keuze tussen een

Dit artikel is geschreven namens Borstkankervereniging Nederland (BVN)/Oncogen.

D. M. Ligtenberg $(\bowtie)$

Borstkankervereniging Nederland (BVN)/Oncogen, Utrecht, Nederland

info@oncogen.nl

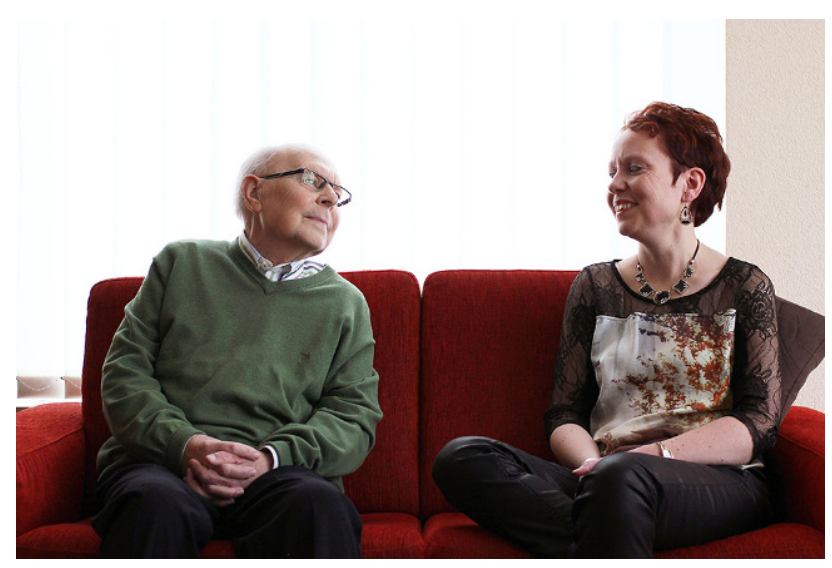

Figuur 1 Béatrice en haar vader. (Foto: Jonas Löllmann)

borstsparende operatie of een borstamputatie.” Béatrice bleek geen mutatie in het BRCA1-, maar in het $B R C A 2-g e n$ te hebben. Zo'n mutatie geeft een risico op borstkanker van $60-80 \%$, een verhoogd risico om een tweede keer borstkanker te krijgen en een risico op eierstokkanker van 10-20\%. "Dat betekende dat ik een grote kans had op een nieuwe tumor in de borst en op eierstokkanker. Mijn eierstokken liet ik daarom ook verwijderen. Jaarlijks krijg ik een MRI-scan van de linkerborst. Een eventuele nieuwe tumor wordt dan tijdig ontdekt, waardoor de prognose gunstiger is. Mogelijk kies ik in de toekomst nog voor een preventie amputatie met reconstructie."

Hoewel aan moederskant een tante borstkanker kreeg op 72-jarige leeftijd, was het waarschijnlijker dat de erfelijke aanleg van vaderskant kwam. Aan die kant kreeg een zus van vader op haar $48^{\mathrm{e}}$ borstkanker en kregen, voordat Béatrice ziek werd, vier mannen prostaatkanker, onder wie dus de vader van Béatrice. Een BRCA2-genmutatie geeft niet alleen een verhoogd risico op borst- en eierstokkanker; ook het 
Figuur 2 Stamboom van Béatrice

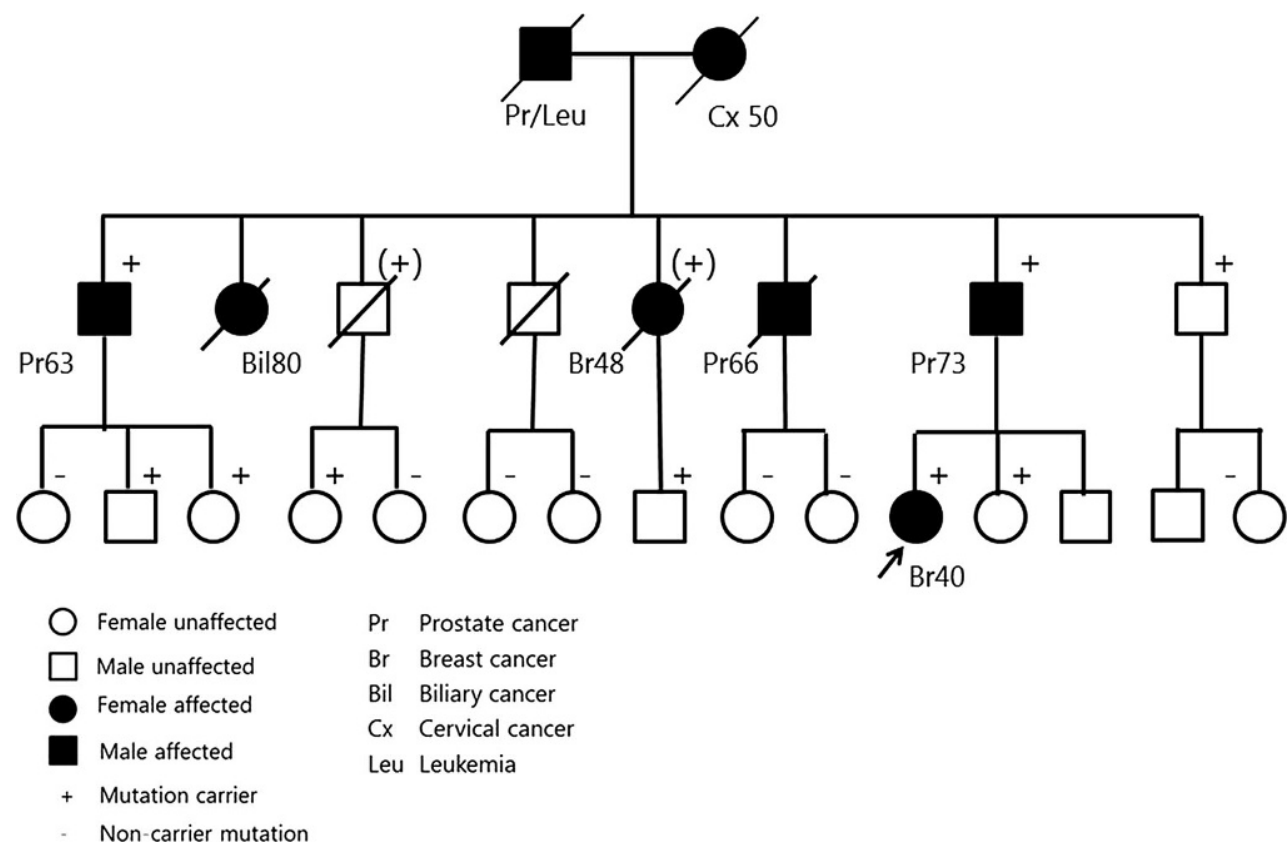

risico voor mannen op prostaatkanker is duidelijk verhoogd. "Om zeker te weten van wie ik de mutatie heb geërfd, moesten mijn ouders zich laten testen", vertelt Béatrice. "Liefst zo snel mogelijk, want ik wilde de rest van de familie waarschuwen. Ik wilde niet dat iemand hetzelfde zou overkomen als wat mij overkwam. Ik had borstkanker met uitzaaiingen in de okselklieren en de lymfeklieren boven het sleutelbeen. Triple negatief ook nog, mijn prognose was niet gunstig."

Zoals verwacht kwam de BRCA2-genmutatie van vaderskant (fig. 2). Een grote klap voor Wim. "Ik voelde me schuldig dat ik het had doorgegeven. Ik weet wel dat ik er niets aan kon doen, maar toch had ik dat gevoel. En nog wel eens. Ik stop dat dan maar weg. Hoe erg ik het ook vind dat Béatrice ziek werd, we weten nu wel waardoor zij, mijn vader, zus en broers door kanker werden getroffen. Dat is belangrijk, zo konden we andere familieleden waarschuwen en kan hun mogelijk veel ellende bespaard blijven." Wim doelt op screening en preventie bij een BRCA-mutatie. Vrouwen met een BRCA-mutatie komen in aanmerking voor periodieke screening van hun borsten. Daardoor kan borstkanker tijdig worden ontdekt. Voor eierstokkanker is screening niet effectief. Bij een BRCA2-genmutatie is het advies om de eierstokken tussen het $40^{\mathrm{e}}$ en $45^{\mathrm{e}}$ levensjaar te verwijderen. Bij BRCAl is dit al tussen de 35 en 40 jaar.

Veel mensen koppelen BRCA aan Angelina Jolie, de Amerikaanse actrice die in 2013 bekendmaakte dat ze een BRCA-mutatie heeft. Inmiddels is redelijk algemeen bekend dat zo'n mutatie een verhoogd risico op borst- én eierstokkanker geeft. Dat de link met prostaatkanker minder bekend is, merkte Béatrice onder andere bij een gesprek met een mammacareverpleeg- kundige in het ziekenhuis. "Toen ik voorafgaand aan de diagnose tegen haar begon over prostaat- en borstkanker in de familie, zei zij stellig: 'Prostaatkanker staat los van borstkanker.' Inmiddels is de combinatie van prostaat- én borstkanker in één tak van de familie in bepaalde gevallen reden voor genetisch onderzoek." Toen Wim prostaatkanker kreeg, werd deze ziekte nog niet gerelateerd aan een BRCA2-genmutatie. Béatrice: "Als ze toen van alle patiënten waren nagegaan of zij in aanmerking kwamen voor een erfelijkheidsonderzoek, was ik eerder op de hoogte geweest van mijn risico's. Waarschijnlijk was mijn borstkanker dan in een eerder stadium geconstateerd. Ik vind dat erg zuur. Het had anders gekund. Daarom vind ik dat urologen alert moeten zijn op belaste families. De prostaatkankerpatiënten in hun spreekkamer zijn weliswaar mannen, maar die hebben zussen, dochters en nichtjes. Achter één patiënt zit een hele familie. De gezondheidswinst is enorm als zij op tijd worden ingelicht. We hebben nog een lange weg te gaan in het informeren van artsen." Béatrice ziet het als een belangrijke missie om de relevantie van erfelijkheidsonderzoek te benadrukken. Daarom werd ze eind 2015 een van de BRCA-ambassadeurs voor de campagne 'Daarom doorvragen' van Borstkankervereniging Nederland. "Op congressen voor zorgprofessionals deelden we flyers uit met ons verhaal, met daarbij een kaartje met de verwijscriteria voor genetisch onderzoek."

Nadat Wim was getest en de mutatie bleek te hebben, informeerde Béatrice de familie van vaderskant hierover. "Ik vond het mijn plicht de kennis die ik had met mijn familieleden te delen. Mensen krijgen er wel een zorg bij, maar het kan ze behoeden voor een nog veel grotere zorg in de toekomst. Als iemand vervolgens niets met die kennis wil doen, is dat zijn of haar 


\title{
Hier staat een advertentie.
}

\author{
cC bohn \\ stafleu \\ van loghum
}

Houten 2020 


\title{
Hier staat een advertentie.
}

\author{
cC bohn \\ stafleu \\ van loghum
}

Houten 2020 
keuze." Van de 12 neven en nichten lieten er uiteindelijk 11 erfelijkheidsonderzoek doen (fig. 2). "Iedereen liet mij de uitslag weten", vervolgt Béatrice. "Sommige nichtjes met een goede uitslag vonden dat lastig, omdat ik de genmutatie wél heb en ook nog kanker kreeg. Bij goed nieuws was ik blij, maar slecht nieuws gaf een dubbel gevoel. Als ik de uitslag van mijn erfelijkheidsonderzoek niet had meegedeeld, hadden mijn familieleden niet voor zulke moeilijke keuzes gestaan. Dan hoefden ze geen screeningsonderzoeken en operaties te ondergaan. Maar ik behoedde hen er tegelijkertijd voor dat ze, zoals ik, als een dief in de nacht door kanker overvallen zouden worden."

Vrouwen met een BRCA-mutatie die (nog) geen kanker hebben, kunnen vanaf hun $25^{\mathrm{e}}$ kiezen voor screening of een preventieve operatie van de borsten. Bij BRCA1 is het advies om tussen de 35 en 40 jaar de eierstokken te laten verwijderen. Bij BRCA2 is dat tussen de 40 en 45 jaar. Ook mannen met een BRCA2mutatie hebben een verhoogd risico op borstkanker, hun lifetime risico wordt geschat op ongeveer $7 \%$. Voor mannen met een BRCA1-genmutatie is het risico op borstkanker $1 \%$. Daarnaast hebben mannen met een BRCA2-mutatie ook een hogere kans op prostaatkanker (20-30\%). Mannen met een BRCA2-mutatie kunnen daarom worden gescreend op prostaatkanker. Het lijkt de moeite waard om zo'n screening op te starten.

De vrouwelijke familieleden van Béatrice en Wim met de mutatie kiezen vooralsnog voor jaarlijkse screening van hun borsten. De overlevingskans bij screening ten opzichte van een preventieve operatie is voor vrouwen met een BRCA2-mutatie nagenoeg gelijk. Bij een nicht van Béatrice werd inmiddels ook borstkanker vastgesteld, in 2017. Doordat de kanker in een eerder stadium werd opgespoord via de MRIscan, is haar prognose gelukkig gunstiger. Wims zoon heeft nog geen erfelijkheidsonderzoek laten doen. "Ik heb daar veel moeite mee", zegt Wim. "Mijn zoon is bijna vijftig, ik moet er niet aan denken dat hij ook ernstig ziek wordt."
Het is niet alleen belangrijk om in het kader van preventie en screening op de hoogte te zijn van een BRCA-mutatie, er is ook een speciale behandeling met PARP-remmers voor mensen met kanker en erfelijke aanleg. Deze PARP-remmers worden ingezet bij eierstokkanker en borstkanker bij vrouwen met een BRCAmutatie. Bij prostaatkanker gebeurt dit vooralsnog alleen in studieverband. "De PARP-remmers hadden bij mij een gunstig effect op de uitzaaiingen in mijn botten en longen", vertelt Wim. "Ik heb alleen de pech dat ik nog maar één nier heb, die bovendien niet heel goed functioneert. De medicijnen hadden na een jaar de nierfunctie zo ver aangetast dat ik ermee moest stoppen. Daar had ik het moeilijk mee. Aan de andere kant ben ik blij dat ik dankzij de PARP-remmers nog wat extra tijd heb gekregen. Én dat ik een dochter als Béatrice heb. De oncoloog kwam namelijk niet zélf met deze behandeloptie; dankzij de zoektocht van Béatrice en haar doorzettingsvermogen kon ik ze uiteindelijk toch krijgen." De twee hebben een bijzondere band, vindt ook Béatrice. "We hebben het er samen niet altijd over, maar doordat we allebei kanker kregen, begrijpen we elkaar." Béatrice tot slot: "Veel liever had ik natuurlijk geen borstkanker gehad. Dan hadden we echter niet geweten van de genmutatie in de familie en zou de studie met PARP-remmers niet onder de aandacht zijn gekomen. Mijn vader schonk mij samen met mijn moeder het leven, en zo gaf ik hem een klein stukje extra leven terug." Wim is inmiddels overleden aan prostaatkanker.

Open Access This article is distributed under the terms of the Creative Commons Attribution 4.0 International License (http://creativecommons.org/licenses/by/4.0/), which permits unrestricted use, distribution, and reproduction in any medium, provided you give appropriate credit to the original author(s) and the source, provide a link to the Creative Commons license, and indicate if changes were made.

Deborah M. Ligtenberg, vrijwilliger Borstkankervereniging Nederland (BVN)/Oncogen 